\title{
PRESTASI BELAJAR MATEMATIKA DITINJAU DARI KEPERCAYAAN DIRI DAN KEAKTIFAN SISWA DI KELAS
}

\author{
MAMAN ACHDIYAT \\ mamanachdiyat9@gmail.com
}

KARTIKA DIAN LESTARI

Program Studi Pendidikan Matematika

Fakultas Teknik Matematika dan IPA Universitas Indraprasta PGRI

\begin{abstract}
The purpose of the study was to analyze whether there is influence confidence and activity of students in the class of the mathematics achievement class VIII SMP Negeri 208 Jakarta. The research method in this study is a survey method through correlation techniques. The population in this study were all students of class VIII SMP 208. Sampling techniques using random sampling techniques,. The amount of a sample group of 40 students. Confidence data collection instruments, and active participation by students in class with each of 30 questionnaires and data collection Mathematics Learning Achievement through documents UAS value. Then test data requirements that normality test with chi-square test, which marks the third data $\mathrm{Xh}<\mathrm{Xt}$, namely Confidence (5.65 $<7.815)$, active participation by students in Grades $(1.42<7.815)$, mathematics Learning Achievement $(0,39<7.815)$, then three normal distribution. The next test of linearity regression with $\alpha=0.05$. Mathematics Learning Achievement on Self Confidence $\mathrm{Fh}<\mathrm{Ft}$ (1.015 <2.35), then $\mathrm{H} 0$ is accepted concluded subsequent linear regression model patterned Mathematics Learning Achievement of the activeness of students in Grades Fh $<$ Ft $(0.4753<2.13) \mathrm{H} 0$ accepted, patterned linear regression model. Hypothesis testing technique used is the technique of double correlation. Double correlation test with $\alpha=$ 0.05 , then to DK1 $=2$ and obtained Ftabel $\mathrm{dk} 2=37=3.25$. Because Fh> Ft $(6.87<3.25)$ is high, we conclude that together a significant difference between Confidence and active participation by students in Grades towards mathematics achievement
\end{abstract}

Keywords: Confidence, liveliness Students in Classroom, Learning Achievement in Mathematics.

Abstrak. Tujuan dari penelitian adalah untuk menganalisa apakah terdapat pengaruh kepercayaan diri dan keaktifan siswa di kelas terhadap prestasi belajar matematika siswa kelas VIII SMP Negeri 208 Jakarta. Metode penelitian dalam penelitian ini adalah metode survei melalui teknik korelasi. Populasi dalam penelitian ini adalah seluruh siswa kelas VIII SMP Negeri 208. Tehnik pengambilan sampel menggunakan teknik random sampling,. Banyaknya kelompok sampel sebanyak 40 siswa. Instrumen pengumpulan data Kepercayaan Diri dan Keaktifan Siswa di Kelas dengan angket masing-masing 30 dan pengambilan data Prestasi Belajar Matematika melalui dokumen nilai UAS. Kemudian uji persyaratan data yaitu uji normalitas dengan uji chi-kuadrat, dimana ketiga datanya menandakan $x_{\mathrm{h}}<\mathcal{X}_{\mathrm{t}}$, yaitu Kepercayaan Diri $(5,65<7,815)$, Keaktifan Siswa di Kelas $(1,42<7,815)$, Prestasi Belajar matematika $(0,39<7,815)$, maka ketiganya berdistribusi normal. Uji selanjutnya kelinearan regresi dengan $\alpha=0,05$. Prestasi Belajar Matematika terhadap Kepercayaan Diri $\mathrm{F}_{\mathrm{h}}<\mathrm{F}_{\mathrm{t}}(1,015<2,35)$, maka $\mathrm{H}_{0}$ diterima disimpulkan model regresi berpola linear selanjutnya Prestasi Belajar Matematika terhadap Keaktifan siswa di Kelas $\mathrm{Fh}<\mathrm{Ft}(0,4753<2,13)$ maka $\mathrm{H}_{0}$ diterima maka model 
regresi berpola linear. Teknik uji hipotesis yang digunakan adalah teknik korelasi ganda. Uji korelasi ganda dengan $\alpha=0,05$, maka untuk $\mathrm{dk}_{1}=2$ dan $\mathrm{dk}_{2}=37$ diperoleh $\mathrm{F}_{\text {tabel }}=$ 3,25 . Karena $F_{h}>F_{t}(6,87<3,25)$ tergolong tinggi maka disimpulkan bahwa secara bersama-sama terdapat pengaruh yang signifikan antara Kepercayaan Diri dan Keaktifan Siswa di Kelas terhadap prestasi belajar matematika

Kata Kunci: Kepercayaan Diri, Keaktifan Siswa di Kelas, Prestasi Belajar Matematika.

\section{PENDAHULUAN}

Pendidikan adalah kebutuhan pokok dalam kehidupan manusia. Berdasarkan undang-undang sisdiknas No. 20 Tahun 2003 Bab 1, pendidikan adalah usaha sadar dan terencana untuk mewujudkan suasana belajar dan proses pembelajaran agar peserta didik secara aktif mengembangkan potensi dirinya untuk memiliki kekuatan spiritual keagamaan, pengendalian diri, kepribadian, kecerdasan, akhlak mulia, serta ketrampilan yang diperlukan bagi dirinya,masyarakat bangsa dan negara. Pendidikan yang terencana sedemikian rupa akan memberikan dampak yang positif yang baik bagi kegiatan belajar.

Dalam proses belajar pada diri siswa diperlukan kondisi belajar, baik kondisi yang berasal dari faktor internal maupun eksternal. Faktor internal adalah faktor yang bersumber dari dalam diri individu itu sendiri, meliputi kondisi fisik dan kondisi psikologis individu. Faktor eksternal adalah merupakan faktor yang datang dari luar diri individu. Faktor eksternal ini dapat dibedakan menjadi tiga, yaitu berasal dari keluarga, sekolah, dan masyarakat.

Kedua faktor tersebut akan membentuk suatu kondisi belajar bagi siswa. Kondisi belajar tersebut yang dapat menghasilkan perubahan perilaku pada siswa, mempengaruhi proses dan prestasi belajar yang dimiliki siswa. Setiap kondisi saling berkaitan dan sangat penting dalam suatu pembelajaran, agar siswa memperoleh hasil belajar yang diharapkan. Ketika kondisi belajar siswa tidak mendukung proses belajar maka akan timbul gangguan dalam belajar sehingga kondisi belajar menjadi tidak kondusif lagi.

Gangguan dalam belajar sering dialami oleh siswa yang cacat-belajar dan berprestasi rendah. Salah satu yang dialami siswa adalah rasa rendah diri, siswa seringkali merasa dirinya tidak percya dan tidak yakin atas kemampuan yang dimilikinya. Padahal siswa yang sukses berani menetapkan cita-cita tinggi karena mereka tidak takut pada kegagalan. Jika mereka tidak berhasil mencapai cita-cita, mereka tidak melihatnya sebagai kegagalan. Bagi mereka itu adalah suatu pelajaran berharga. Dengan demikian mereka tidak merasa kecewa ketika prestasi belajar mereka tidak seperti yang mereka harapkan. Mereka tahu selama mempelajari sesuatu dan tetap berusaha, akhirnya akan meraih prestasi yang gemilang.

Tetapi kenyataannya menurut Khoo (2009: 19) hanya sebanyak $5 \%$ siswa yang percaya diri pasti berhasil karena mereka berpikir bahwa keberhasilan adalah suatu keharusan. Sedangkan 95\% tidak percaya diri dan hanya berharap tanpa berpikir bahwa keberhasilan adalah suatu keharusan. Biasanya siswa yang tidak percaya diri dikarenakan siswa memiliki pengalaman sekolah yang negatif sehingga meruntuhkan rasa percaya diri dan kecintaan alamiah mereka pada belajar. Pengalaman tersebut yang menyebabkan siswa takut untuk mencoba dan belajar kembali tanpa kenal putus asa.

Siswa cenderung membenci matematika dan terlanjur menganggap matematika itu sulit. Bahkan anggapan tersebut semakin berkembang ketika orang-orang di lingkungan siswa memberikan label gagal pada siswa yang memiliki hasil belajar rendah. Anggapan tersebut membentuk keyakinan negatif didalam diri mereka. Padahal kepercayaan diri terbentuk dari dalam diri dan dari lingkungan siswa. Ketika lingkungannya tidak mendukungnya untuk memahami kekurangan dan tidak membantunya untuk melihat 
kelebihan dan potensi yang ada di dalam diri siswa pada akhirnya menyebabkan terkikisnya rasa percaya diri.

Siswa cenderung takut akan kegagalan, khawatir tinggal kelas, takut disebut bodoh, dan takut akan menyadari bahwa diri mereka sendiri memang bodoh. Selain itu, siswa seringkali takut melakukan kesalahan, menerima ejekan baik dari teman-teman satu kelas mereka atau dari guru. Maka seperti yang di ungkapkan Holt (2012: 96) "siswa mulai membatasi diri dan melemahkan diri mereka (self-defeating) kebanyakan karena rasa takut". Mereka berusaha melindungi diri sendiri, dan dalam kondisi apapun akan ditunjukan terutama untuk menghilangkan rasa malu, hukuman, penolakan, kemarahan guru, atau kehilangan status.

Siswa menjadi lebih bersikap pasif dalam proses pembelajaran dan membuat siswa enggan aktif dalam kegiatan dikelas. Padahal setiap siswa memiliki kemampuan belajar dan kesempatan yang sama bahkan pada dasarnya setiap siswa memiliki kepercayaan, sikap, perasaan, cita-cita akan dirinya, ada yang realistis atau justru tidak realistis. Hanya saja dalam proses belajarnya dirusak oleh berbagai sugesti negatif yang diperoleh siswa dari lingkungannya.

Perlahan-lahan kepercayaan diri siswa menjadi terkikis. Siswa mulai bersikap apatis, tidak peduli, dan menyerah pada akhirnya. Belajar hanya menjadi sebuah formalitas dan hanya menjadi sebuah aktivitas yang harus dijalani, prestasi belajar tidak lagi menjadi tujuan dan akhirnya siswa tidak lagi termotivasi meraih yang terbaik dalam belajarnya.

Kepercayaan diri penting untuk menciptakan keberanian siswa menunjukan kemampuan yang dimilikinya tanpa mempedulikan lingkungannya yang tidak kondusif. Selain itu kepercayaan diri mampu menciptakan tujuan dalam meraih prestasi belajar yang terbaik, membangun kekuatan dalam diri siswa untuk terus belajar. Kekuatan belajar yang timbul dalam diri siswa akan menciptakan perubahan dan perbaikan diri karena ketika siswa yakin pada diri sendiri, siswa bebas mengarahkan perhatian dan perbaikan diri dan pencapaian kekuatan belajar yang dimiliki oleh siswa.

Ketika rasa percaya diri itu muncul siswa merasa bebas menunjukan kemampuannya, aktif dalam kegiatan pembelajaran dikelas tanpa takut terhadap kegagalan. Kesempatan berbicara dan mengemukakan pemikiran mereka tanpa takut gagal mendorong siswa menjadi lebih aktif. Keaktifan merupakan salah satu dari tiga prinsip pembelajaran efektif bagi pendidikan, seperti yang dinyatakan Megawangi (2008: 40) bahwa "Pembelajaran memerlukan partisipasi aktif siswa (belajar aktif).

Keaktifannya dalam kegiatan pembelajaran menjadi sangat penting untuk meraih prestasi belajar. Siswa memiliki rasa ingin tahu yang tinggi sehingga pada dasarnya siswa senang bertanya. Rasa percaya diri dalam diri siswa mendorong keingintahuan untuk bertanya dan aktif dalam kegiatan pembelajaran sehingga meningkatkan prestasi belajar. Keterlibatan aktif anak dalam proses belajar adalah inti dari proses belajar yang efektif.

Guru tidak lagi mendominasi kelas dan tidak menjadi sentral pembelajaran. Siswa mulai belajar aktif dan lebih dominan dalam belajar. Siswa belajar menggunakan seluruh kemampuannya. Siswa dituntut percaya diri dan aktif dalam semua kegiatan belajar. Diharapkan dengan rasa percaya diri yang tinggi mendorong keaktifan siswa menjadi lebih maksimal.

Atas dasar uraian itulah, melalui penelitian ini penulis mencoba melakukan tinjauan analisis tentang pengaruh kepercayaan diri dan keaktifan siswa terhadap prestasi belajar siswa kelas VII SMP Negeri 208 Ciracas Jakarta Timur. 


\section{TINJAUAN PUSTAKA}

\section{Prestasi Belajar Matematika}

Syah (2010: 93) mengatakan bahwa "belajar adalah key term yang paling vital dalam usaha pendidikan". Belajar menjadi tempat yang luas dalam berbagai disiplin ilmu berkaitan dengan pendidikan. Suatu pendidikan berjalan ketika adanya proses belajar. Belajar menjadi kunci utama dalam sebuah pendidikan, tanpa belajar pendidikan tidak bisa berlangsung. Dalam belajar melibatkan banyak hal, seperti penemuan-penemuan terbaru yang berkenaan dengan teori belajar, metode pembelajaran, model pembelajaran, strategi pembelajaran, guru, siswa, pemerhati pendidikan, dan lingkungan. Seperti yang diungkapkan oleh Swadarma (2013: 1) bahwa "belajar adalah proses yang melibatkan banyak hal".

Khoo (2009: 7) mendefinisikan bahwa "belajar adalah melihat, mengamati, mencatat, dan menyimpannya dalam memori otak berulang-ulang”. Belajar diawali ketika timbul rasa ingin tahu siswa saat melihat sesuatu yang menarik, kemudian mengamati, mencatat bagian yang menarik, kemudian menyimpannya dalam memori otak berulang terus menerus saling berkesinambungan. Sementara Hamalik (Susanto, 2014: 3) menjelaskan bahwa "belajar adalah memodifikasi atau memperteguh perilaku melalui pengalaman (learning is defined as the modificator or strengthening of behaviour through experiencing)". Dari pengalaman yang dimiliki terbentuk suatu perilaku yang berubah menjadi semakin kuat dan disesuaikan dengan keadaan dan lingkungan, perubahan tersebut tidak mementingkan suatu hasil atau tujuan tapi lebih mengutamakan proses.

Perubahan tersebut terjadi secara alamiah tanpa paksaan dan memanfaatkan kemapuan berpikir yang dimiliki oleh setiap individu yang sejak awal difungsikan sedemikian rupa seperti yang dikatakan oleh Holt (2012: vii) bahwa "belajar adalah menggunakan kemampuan berpikir yang alamiah." Thordike (Swadarma, 2013: 103) mengatakan bahwa belajar adalah "hubungan antara stimulus dan respon". Belajar menggunakan kemampuan berpikir yang muncul secara alamiah, belajar dengan cara coba-coba dan salah dari suatu stimulus yang terdapat disekitar dan mendapatkan respon yang berbeda. Asosiasi antara stimulus dan respon saling berhubungan satu dengan yang lain

Perubahan berawal dari yang tahu menjadi yang tidak tahu, dari yang salah menjadi benar. Ketika respon mulai muncul diharapkan adanya perubahan sebelum dan sesudahnya munculnya stimulus. Seperti yang diungkapkan Houston (Syah, 2001: 45) bahwa "belajar adalah respon-respon terhadap stimulus yang disebut instrumental (penolong) yang berguna untuk memperoleh sesuatu atau perubahan yang diharapkan.”

Hilgard (Susanto, 2014: 3) mendefinisikan bahwa "belajar adalah suatu perubahan kegiatan reaksi terhadap lingkungan . Perubahan tersebut berawal dari adanya reaksi yang terjadi antara diri siswa terhadap lingkungan. Kegiatan tersebut menyangkup pengetahuan, kecakapan dan tingkah laku. Reaksi tersebut dipengaruhi oleh beberapa faktor. Adapun menurut Hamdani (2013: 163) "faktor - faktor yang mempengaruhi proses belajar pada siswa antara lain kemampuan, kemauan dan umur". Kemampuan yang bagus dan memiliki kemauan dalam belajar serta umur yang cukup membantu untuk mewujudkan terjadi belajar yang maksimal.

Berdasarkan uraian diatas, maka dapat disimpulkan belajar merupakan unsur yang sangat fundamental dalam penyelenggaraan pendidikan yang tercipta dari suatu kemampuan berpikir alamiah yang menyangkut hubungan antara stimulus dan respon yang berlangsung terus-menerus dan merupakan reaksi yang dipengaruhi oleh faktorfaktor proses belajar terhadap lingkungan sehingga terbentuk perubahan yang berasal dari pengalaman. Adapun menurut Gunarso (Hamdani, 2013: 21) "prestasi belajar adalah usaha maksimal yang dicapai oleh seseorang setelah melaksanakan usaha-usaha belajar". 
Bentuk usaha maksimal tersebut berupa nilai, perubahan atau tingkatan setelah melalui proses belajar mengajar didalam kelas. Untuk mendapatkan usaha maksimal dibutuhkan usaha yang terus menerus.

Seperti yang diungkapkan oleh Hamdani (2013: 21) bahwa "Prestasi belajar merupakan suatu bentuk nyata pencapaian seorang siswa dalam belajar." Bentuk nyata pencapaian seorang siswa dapat berupa perubahan positif. Perubahan positif tersebut merupakan bentuk pemahaman siswa yang diukur melalui tes setelah terjadinya proses belajar mengajar. Hamalik (2004: 159) menyatakan bahwa "prestasi belajar merupakan indikator adanya perubahan tingkah laku siswa". Prestasi adalah hasil maksimal dari sesuatu, baik berupa belajar mapun bekerja. Indikator prestasi biasanya merupakan bentuk perubahan baik berupa nilai maupun sikap.

Surya (Syah, 2001: 151) menjelaskan bentuk bentuk prestasi. Jenis prestasi tersebut dibedakan menjadi 3, yaitu: 1) Ranah kognitif meliputi pengamatan, ingatan, pemahaman, penerapan, analisis, sintesis, 2)Ranah afektif meliputi penerimaan, sambutan, apresiasi, internalisasi, karakteristik, dan 3) Ranah psikomotorik meliouti ketrampilan bergerak dan bertindak, kecakapan ekspresi verbal dan nonverbal. Dalam meraih keberhasilan tersebut ada banyak faktor yang mempengaruhi prestasi belajar, faktor tersebut bisa berasal dari dalam diri maupun dari luar. Menurut Ahmadi (Leonard, 2012: 105), "faktor-faktor yang mempengaruhi prestasi belajar siswa secara garis besar terbagi dua yaitu: 1) yang tergolong faktor internal adalah: faktor jasmaniah (fisiologi) dan faktor psikologis. 2) yang tergolong faktor eksternal adalah: faktor sosial, faktor budaya, dan faktor lingkungan fisik".

Berdasarkan dari berbagai definisi maka prestasi belajar adalah bentuk nyata usaha maksimal pencapaian siswa yang ditandai dengan adanya indikator perubahan positif tingkah laku siswa yang dipengaruhi oleh faktor internal dan faktor eksternal. Berdasarkan jenisnya prestasi siswa dibedakan menjadi tiga jenis ranah kognitif, afektif, dan psikomotorik dan untuk mengukurnya digunakan tes.

\section{Konsep Matematika}

Kata matematika berasal dari perkataan Latin mathematica yang mulanya diambil dari perkataan Yunani mathematike yang berarti mempelajari. Perkataan itu mempunyai asal katanya mathema yang berarti pengetahuan atau ilmu (knowledge, science).

Depdiknas (Susanto, 2014: 184) menjelaskan bahwa "matematika dalam bahasa belanda disebut wiskunde atau ilmu pasti, yang kesemuanya berkaitan dengan penalaran". Matematika merupkan salah satu ilmu pasti, ilmu dari dasar ilmu pengetahuan yang dalam memahaminya dibutuhkan penalaran, saling berkaitan satu sama lain.

James (Slameto, 2003: 27) mengatakan bahwa "Matematika adalah ilmu tentang logika mengenai bentuk, susunan, besaran, dan konsep-konsep yang saling berhubungan satu sama lainnya dengan jumlah yang banyaknya terbagi ke dalam tiga bidang, yaitu aljabar, analisis, dan geometri." Susunan konsep-konsep yang saling berhubungan membentuk suatu sistem dan menjadi satu dalam matematika.

Sedangkan Abdurahman (2000: 11), mengatakan bahwa "matematika adalah pola berfikir atau bahasa yang menggunakan istilah yang didefinisikan dengan cermat, jelas, dan akurat". Matematika merupakan pola bahasa yang menunjukan kejelasan dengan cermat dan akurat dimana penggunaannya tanpa dilebih-lebihkan.

Matematika merupakan suatu ilmu yang terancang sangat teratur saling berkaitan dan biasanya berupa simbol-simbol angka maupun opersai pengerjaannya. Seperti yang diungkapkan Ruseffendi (Hamalik, 2004: 12) bahwa "Matematika adalah bahasa simbol, ilmu deduktif, yang tidak menerima pembuktian secara induktif, ilmu tentang pola keteraturan, ilmu tentang struktur yang terorganisasi”. 
Romberg (Sofan, 2010: 56) menyatakan "matematika sebagai konstruksvisme sosial dengan penekanannya pada knowing, yaitu pembelajar dipandang sebagai makhluk yang aktif dengan cara berinteraksi dengan lingkungannya." Matematika adalah pembangun dalam kehidupan sosial, seorang yang belajar matematika adalah orang yang aktif karena interaksinya terhadap lingkungan.

Sulistyarin (Trianto, 2012) menyatakan "matematika adalah ilmu yang mempelajari tentang cara penalaran logis yang memiliki nilai praktis, disiplin dan budaya dengan objek berupa ide atau konsep abstrak yang tersusun secara hierarki yang diwujudkan dalam bentuk simbol-simbol serta penalarannya bersifat deduktif". Berdasarkan dari berbagai definisi maka matematika adalah ilmu pasti yang menggunakan pola bahasa yang cermat, jelas dan akurat dengan menerapkan penalaran logika dan saling berhubungan sama lain biasanya berupa simbol-simbol yang tersusun sedemikian rupa yang digunakan sehari-hari. Astuti (2012: 106) "prestasi belajar adalah hasil yang diperoleh siswa dari proses pembelajaran matematika yang meliputi proses perubahan tingkah laku yang menghasilkan perubahan-perubahan dalam pengetahuan terutama penguasaan bahan belajar matematika". Untuk menguasai bahan belajar matematika dibutuhkan proses. Selama proses tersebut terdapat perubahan-perubahan baik dalam penambahan pengetahuan maupun penguasaan materi.

Prestasi belajar matematika dapat diukur dengan skor yang menunjukan tingkat pengusaan materi setelah menempuh proses belajar. Nasution (2010: 150) mengungkapkan bahwa "prestasi belajar matematika adalah skor yang mencerminkan terhadap penguasaan matematika di sekolah yang telah menempuh proses belajar dan diukur dengan tes". Tes tersebut dapat berupa tes harian, tes formatif, atau tes pada akhir semester.

Leonard (2013: 101) mengungkapkan bahwa "prestasi belajar matematika adalah skor tentang kemampuan atau tingkat penguasaan materi pelajaran berupa konsep matematika yang diperoleh siswa selama proses belajar mengajar dan mampu memecahkan masalah matematika sesuai dengan tujuan pembelajaran matematika. Skor tersebut didapat melalui tes yang berisi konsep-konsep matematika dan siswa tersebut telah dinyatakan mampu memecahkan masalah sesuai tujuan pembelajaran matematika.

Berdasarkan dari berbagai definisi maka prestasi belajar matematika adalah hasil yang diperoleh siswa selama proses pembelajaran matematika dan mampu memecahkan masalah matematika sesuai dengan tujuan pembelajaran matematika yang meliputi proses perubahan tingkah laku, kemampuan atau tingkat penguasaan materi dapat berupa skor dan diukur dengan tes.

\section{Kepercayaan Diri}

Setiap manusia memiliki kepribadian yang berbeda dalam diri mereka, begitu pula halnya pada seorang siswa. Didalam diri terdapat kepribadian yang meliputi banyak aspek. Mahmud (Leonard, 2013: 99) mengungkapkan bahwa "Diri itu berasal dari kata self, merupakan salah satu aspek sekaligus inti kepribadian seseorang yang didalamnya meliputi segala kepercayaan, sikap, perasaaan dan cita-cita".

Salah satu aspek yang terpenting dalam diri seorang siswa adalah kepercayaan. Kepercayaan diri berasal dari dalam jiwa bahwa kehidupan seperti apapun harus dihadapi. Seperti yang diungkapakan oleh Angelis (2007: 10) bahwa "Percaya diri merupakan suatu keyakinan dalam jiwa manusia bahwa tantangan hidup apapun harus dihadapi dengan berbuat sesuatu. Percaya diri itu lahir dari kesadaran bahwa jika memutuskan untuk melakukan sesuatu, sesuatu itu pula yang harus dilakukan."

Kepercayaan diri merupakan kemampuan melihat usaha untuk mengggali potensi diri yang tersembunyi kemudian mengembangkannya dan mampu memanfaatkannya 
dengan baik. Seperti diungkapkan bahwa "kepercayaan diri adalah kemampuan melihat, menggali, mengembangkan, dan memanfaatkan potensi diri secara maksimal". (Pabhicara, 2007: 34). Leonetti (Mulya, 2012: 221) mendefinisikan bahwa "percaya diri adalah kepercayaan seseorang dalam kesanggupannya untuk melaksanakan tugas atau pekerjaan”. Kepercayaan akan kesanggupan menghadapi tantangan hidup baik yang berupa pekerjaan ataupun tugas merupakan bentuk kepercayaan diri. Semakin sanggup untuk melaksanakan tugas menunjukan semakin besar pula kepercayaan diri, begitu pula sebaliknya.

Bandura (Widiastuti, 2009: 149) mengatakan bahwa "kepercayaan diri merupakan salah satu bagian dari self-efficacy". Self-efficacy dapat meningkat atau menurun melalui persuasi orang lain pada kondisi adanya rasa percaya kepada yang memberikan persuasi secara verbal. Membuat keyakinan menjadi suatu kenyataan membutuhkan keterampilan dan tindakan yang mendukung terutama adalah bagian kepercayaan diri.

Siswa yang percaya diri mampu mengubah dirinya dari yang tertekan dan depresi menghadapi kesulitan belajar menjadi siswa yang bertekad bulat untuk mampu dan berhasil dalam belajar. "kepercayaan diri adalah kemampuan mengubah perasaan yang semula depresi menjadi bertekad bulat" (Nierenberg, 2012: 108).

Siswa yang percaya diri memilki kemampuan mengaktualisasikan diri, memiliki kecerdasan emosi dan sosial, memiliki motivasi dan berkarkter terbuka seperti. Ikeda (2012: 173) mengungkapkan bahwa siswa yang percaya diri adalah siswa yang memilki kemampuan antara lain:

1) Self Actualization, meliputi kemapuan berkreasi dan mengekpresikan diri, memiliki keyakinan pada kemampuan dan potensi sejati

2) Esteem Needed, meliputi kemampuan berusaha sebaik mungkin untuk meraih prestasi yang baik

3) Kecerdasan emosi ( Social Skill), meliputi pembawaan yang baik dan terasah, mampu menyesuaikan diri dengan lingkungan Mampu menghadapi kritikan dan memiliki penerimaan diri.

4) Motivasi, meliputi kemampuan berpikir positif dan optimisme, mampu menghadapi masalah dan bersikap tenang.

5) Karakter Ekstrovert, meliputi mampu mencermati makna kegagalan, mampu mengubah hidup dan keluar dari masalah dan berbicara dengan lancar

Ada lima cara untuk menumbuhkan keyakinan dan kepercayaan diri yang umum dimiliki siswa - siswa sukses (Khoo, 2009: 35). Lima bentuk cara untuk menumbuhkan keyakinan dan kepercayaan diri tersebut antara lain: 1) Untuk mengubah sesuatu, saya harus berubah dulu, 2) Tidak ada kegagalan, hanya sebuah timbal balik, 3) Jika yang lain bisa, saya juga bisa, 4) Belajar adalah bermain, dan 5) Fleksibilitas membuat anda dapat mengendalikan.

Berdasarkan dari berbagai definisi maka kepercayaan diri adalah keyakinan yang berasal dari diri dan jiwa yang berupa kesaggupan dalam menghadapi tantangan dan perseolan yang dibutuhkan keterampilan dan prinsip untuk menumbuhkannya sehingga mampu keluar dari perasaan depresi menjadi bertekad bulat.

\section{Keaktifan Siswa}

Salah satu usaha belajar adalah aktif dalam kelas. keaktifan siswa adalah pada waktu guru mengajar. Usaha belajar berupa perubahan antara interaksi siswa dengan siswa, atau interaksi siswa dengan guru didalam kelas. Karena keaktifan terjadi karena adanya usaha dari siswa yang bersangkutan (Syafaruddin, 2005: 213). Usaha menciptkan keaktifan belajar siswa dapat dilakukan melalui beberapa faktor. Faktor-faktor yang mempengaruhi keaktifan belajar siswa (Holt, 2010: 210) yaitu: 1) Memberikan dorongan 
atau menarik perhatian siswa, sehingga mereka dapat berperan aktif dalam kegiatan pembelajaran, 2) Menjelaskan tujuan intruksional (kemampuan dasar kepada siswa), 3) Mengingatkan kompetensi belajar kepada siswa, 4) Memberikan stimulus (masalah,topik dan konsep yang akan dipelajari), 5) Memberi petunjuk kepada siswa cara mempelajarinya, 6) Memunculkan aktivitas, partisipasi siswa dalam kegiatan pembelajaran, 7) Memberi umpan balik (feed back), 8) Melakukan tagihan-tagihan kepada siswa berupa tes, sehingga kemampua siswa selalu terpantau dan terukur, dan 9) Menyimpulkan setiap materi yang disampaikan di akhir pelajaran.

Interaksi tersebut dapat berupa kata-kata, mendengarkan, berbicara, membaca dan mengeluarkan dengan baik. Seperti yang diungkapkan Holt (2010: 147) Keaktifan adalah "Ketika kita semakin baik menggunakan kata-kata, apakah mendengarkan, berbicara, membaca, untuk mengungkapkan sesuatu yang ingin kita ungkapkan dengan maksud kita sendiri. Keaktifan belajar adalah adanya aktivitas siswa selama pembelajaran meliputi beberapa hal, yaitu perhatian, kerjasama dan hubungan sosial, mengemukakan gagasan, pemecahan masalah dan disiplin. Seperti yang diungkapkan oleh Ardhana (2009) indikator keaktifan siswa dalam belajar antara lain: 1) Perhatian siswa terhadap penjelasan guru, 2) Kerjasamanya dalam kelompok, 3) Kemampuan siswa mengemukakan pendapat dalam kelompok ahli, 4) Kemampuan siswa mengemukakan pendapat dalam kelompok asal, 5) Memberi kesempatan berpendapat kepada teman dalam kelompok, 6) Mendengarkan dengan baik ketika teman berpendapat, 7) Memberi gagasan yang cemerlang, 8) Membuat perencanaan dan pembagian kerja yang matang, 9) Keputusan berdasarkan pertimbangan anggota yang lain, 10) Memanfaatkan potensi anggota kelompok, dan 11) Saling membantu dan menyelesaikan masalah.

Keaktifan siswa ditunjukkan dengan adanya ketertiban intelektual dan emosional yang tinggi dalam proses belajar. Siswa yang aktif diberikan kesempatan untuk berdiskusi mengemukakan pendapat dan idenya, melakukan eksplorasi terhadap materi yang sedang dipelajari serta menafsirkan hasilnya secara bersama-sama di dalam kelompok. Dari kegiatan tersebut keaktifan siswa terbentuk seperti yang diungkapkan Djamarah (2010: 362) bahwa "kegiatan tersebut memungkinkan siswa berinteraksi aktif dengan lingkungan dan kelompoknya, sebagai media untuk mengembangkan kemampuannya"

Beberapa bentuk kegiatan keaktifan belajar siswa dikelas menurut Dierich (Hamalik, 2004: 172) adalah: 1) Kegiatan-kegiatan visual. Kegiatan ini meliputi membaca, melihat, mengamati, mendemonstrasikan, dan pameran, 2) Kegiatankegiatan lisan. Kegiatan ini meliputi mengemukakan pendapat, wawancara, bertanya, diskusi, dan interupsi, 3) Kegiatan-kegiatan mendengarkan. Kegiatan ini meliputi mendengarkan pelajaran, mendengarkan diskusi kelompok, 4) Kegiatankegiatan menulis. Kegiatan ini meliputi menulis cerita, mengerjakan tes, dan menulis karangan, 5) Kegiatan-kegiatan menggambar. Kegiatan ini meliputi menggambar grafik, diagram peta, dan pola, 6) Kegiatan-kegiatan metrik. Kegiatan ini meliputi melakukan percobaan, memilih alat-alat, dan membuat model, 7) Kegiatan-kegiatan mental. Kegiatan ini meliputi mengingat, merenungkan, dan memecahkan masalah, dan 8) Kegiatan-kegiatan emosional. Kegiatan ini meliputi minat, membedakan, berani, tenang, dan lain-lain.

Keaktifan siswa di kelas menciptakan banyak manfaat bagi diri siswa. Siswa menjadi lebih berinisiatif, mandiri, mampu menyelesaikan masalahnya, dan siap dengan banyak masalah dan peroalan diluar nanti. Franky (2009: 92) menjelaskan bahwa siswa yang aktif akan belajar lebih banyak, lebih berinisiatif, sehingga lebih berpeluang menjadi manusia yang mandiri. Disamping ilmu pengetahuan yang akan lebih melekat karena 
dicari dan dialami sendiri perolehannya, siswa dan lulusan akan lebih siap menghadapi berbagai persoalan karena sudah terbiasa menghadapinya secara mandiri.

Untuk mendukung keaktifan siswa dalam belajar dibutuhkan prinsip-prinsip. Terdapat beberapa prinsip yang perlu diingat, untuk menciptkan keaktifan seorang anak (Holt, 2010: 231) yakni: 1) anak - anak tidak perlu "diajari" agar mereka belajar; mereka akan banyak dan bahkan juga belajar paling baik tanpa di ajari, 2) anak - anak sangat tertarik dengan dunia orang dewasa dan apa yang kita lakukan didalamnya, dan 3) Anak anak belajar paling baik ketika hal - hal yang mereka pelajari terkait dengan konteks hidup yang nyata;

Berdasarkan dari berbagai definisi maka keaktifan siswa dikelas adalah perubahan yang berupa usaha yang berkembang semakin baik dalam bentuk mendengarkan, berbicara, atau mengeluarkan pendapat sehingga menciptakan banyak manfaat dan diperlukan prinsip untuk mengembangkannya

\section{METODE}

Metode yang digunakan dalam penelitian ini adalah metode survei dengan analisis korelasi ganda dan uji regresi ganda. Tujuan dari penelitian korelasional adalah untuk mendeteksi kaitan faktor variasi tertentu dengan faktor variasi lain. Populasi adalah suatu kumpulan menyeluruh dari suatu objek yang merupakan perhartian peneliti (Kountur, 2009: 145). Objek penelitian berupa seluruh anggota dalam lingkup yang dimaksud. Populasi dalam penelitian ini menjadi dasar penentuan sampel penelitian, yaitu Seluruh siswa kelas VIII SMP Negeri 208 Jakarta ada 8 kelas yaitu VIII-1, VIII-2, VIII-3, VIII-4, VIII-5, VIII-6, VIII-7 dan VIII-8 SMP Negeri 208 Jakarta pada semester 2 Tahun pelajaran 2013/2014 dan seluruhnya berjumlah 263 siswa.

Sampel adalah bagian dari populasi (Kountur, 2009: 149). Teknik pengambilan sampel disebut teknik sampling. Untuk menyederhanakan proses pengumpulan data dan pengolaahan data maka sampel yang diambil sebanyak lebih kurang 15\% dari seluruh jumlah populasi. Menurut Arikunto (2006: 107) "Apabila subyeknya kurang dari 100, lebih baik diambil semua sehingga penelitiannya merupakan penelitian populasi. Selanjutnya jika jumlah subyeknya lebih besar, dapat diambil 10-15\%, atau 20-25\%, atau lebih. Maka pada penelitian ini, dilakukan pemilihan 40 siswa, yang diambil dari dua kelas yaitu kelas VIII-6 dan VIII-8 yang berada di SMP Negeri 208 Ciracas Jakarta Timur, tahap pengambilan sampel dapat digambarkan sebagai berikut:

\section{HASIL DAN PEMBAHASAN}

Berdasarkan hasil penelitian dan hasil pengujian hipotesis, maka terbukti bahwa terdapat pengaruh positif Kepercayaan Diri dan Keaktifan Siswa di Kelas secara bersamasama terhadap Prestasi Belajar Matematika. skor koefesien korelasi dengan skor $r_{y x_{1} x_{2}}=$ 0,72. Sedangkan kekuatan sumbangan ditunjukan dengan koefisien determinasi sebesar 0,5202 yang menunjukan bahwa kontribusi kepercayaan diri dan keaktifan siswa di kelas terhadap Prestasi Belajar Matematika sebesar 52,02 \%. Prestasi belajar matematika akan semakin baik jika kepercayaan diri dan keaktifan dikelas semakin ditingkatkan.

Siswa yang percaya diri memiliki keyakinan yang berasal dari diri dan jiwa yang berupa kesaggupan dalam menghadapi tantangan dan perseolan yang membutuhkan keterampilan dan prinsip untuk menumbuhkannya sehingga mampu keluar dari perasaan depresi menjadi bertekad bulat dengan deminkian siswa mampu meraih presatsi belajar yang baik. Hal ini ditujukan dengan diperoleh skor koefesien korelasi yang ditunjukan dengan skor $r_{y x_{1}}=0,67$. Sedangkan kekuatan sumbangan ditunjukan dengan koefisien determinasi sebesar 0,4489 yang menunjukan bahwa kontribusi kepercayaan diri terhadap Prestasi Belajar Matematika sebesar 44,89 \%. Ini menunjukan bahwa terdapat pengaruh 
positif Kepercayaan Diri Siswa terhadap Prestasi Belajar Matematika. Sebaliknya siswa yang memiliki kepercayaan diri yang rendah maka prestasi belajar matematikanya cenderung rendah pula.

Selain Kepercayaan Diri, Keaktifan siswa dikelas berperan pula dalam upaya meraih prestasi belajar matematika, Maka dari itu siswa yang aktif adalah siswa yang mampu membuat perubahan yang berupa usaha yang berkembang semakin baik dalam bentuk mendengarkan, berbicara, atau mengeluarkan pendapat sehingga menciptakan banyak manfaat dan diperlukan prinsip untuk mengembangkannya sehingga siswa mampu mendapatkan presatasi belajar matematika yang baik. Hal ditunjukan dengan diperoleh skor koefesien korelasi yang ditunjukan dengan skor $r_{y x_{2}}=0,65$. Sedangkan kekuatan sumbangan ditunjukan dengan koefisien determinasi sebesar 0,4225 yang menunjukan bahwa keaktifan siswa di kelas terhadap Prestasi Belajar Matematika sebesar $42,25 \%$. Hal ini berarti bahwa terdapat pengaruh positif keaktifan siswa di kelas terhadap prestasi belajar matematika. Siswa yang aktif mampu meraih prestasi belajar matematika dibandingkan dengan siswa yang pasif sebaliknya siswa yang pasif menyebabkan prestasi belajar matematika dicapainya kurang baik.

\section{PENUTUP}

\section{Simpulan}

Pada bagian kesimpulan ini, penulis uraikan secara singkat hasil penelitian yang diperoleh di lapangan. Setelah diadakan penelitian dan analisis data tentang "Pengaruh Kepercayaan Diri dan Keaktifan Siswa di Kelas terhadap Prestasi Belajar Matematika" dapat ditarik kesimpulan sebagai berikut:

1. Terdapat pengaruh secara bersama-sama Kepercayaan Diri ( $\left.X_{1}\right)$ dan Keaktifan Siswa di Kelas $\left(\mathrm{X}_{2}\right)$ terhadap Prestasi Belajar Matematika (Y) dengan mendasar pada skor koefesien korelasi atau hubungan positif yang ditunjukan dengan skor $r_{y x_{1} x_{2}}=0,72$. Sedangkan kekuatan sumbangan ditunjukan dengan koefisien determinasi sebesar 0,5205 yang menunjukan bahwa kontribusi kepercayaan diri dan keaktifan siswa di kelas terhadap Prestasi Belajar Matematika sebesar 52,05 \%. Dengan demikian Kepercayaan Diri dan Keaktifan Siswa di Kelas berperan sangat penting dalam menentukan dan meningkatkanPrestasi Belajar matematika.

2. Terdapat pengaruh Kepercayaan Diri $\left(\mathrm{X}_{1}\right)$ terhadap Prestasi Belajar Matematika (Y) dengan mendasar pada skor koefesien korelasi atau hubungan positif yang ditunjukan dengan skor $r_{y x_{1}}=0,68$. Sedangkan kekuatan sumbangan ditunjukan dengan koefisien determinasi sebesar 0,4471yang menunjukan bahwa kontribusi kepercayaan diri dan keaktifan siswa di kelas terhadap Prestasi Belajar Matematika sebesar 44,71 $\%$. Dengan demikian Kepercayaan Diri Siswa di Kelas berperan sangat penting dalam menentukan dan meningkatkan Prestasi Belajar Matematika.

3. Terdapat pengaruh Keaktifan Siswa di Kelas $\left(\mathrm{X}_{2}\right)$ terhadap Prestasi Belajar Matematika (Y) dengan mendasar pada skor koefesien korelasi atau hubungan positif yang ditunjukan dengan skor $r_{y x_{2}}=0,65$. Sedangkan kekuatan sumbangan ditunjukan dengan koefisien determinasi sebesar 0,4279 yang menunjukan bahwa kontribusi kepercayaan diri dan keaktifan siswa di kelas terhadap Prestasi Belajar Matematika sebesar 42,279 \%. Dengan demikian Keaktifan Siswa di Kelas berperan sangat penting dalam menentukan dan meningkatkan Prestasi Belajar Matematika.

Berdasarkan temuan penelitian di atas yang didasarkan pada analisis data penelitian, bahwa Prestasi Belajar Matematika siswa dapat ditingkatkan dengan cara meningkatkan Kepercayaan Diri dan Keaktifan di Kelas yang lebih baik lagi. 
Saran berikut:

Berdasarkan kesimpulan di atas peneliti mengusulkan beberapa saran sebagai

1. Guru matematika hendaknya terus-menerus membantu siswa meningkatkan rasa percaya diri dan mendukung siswa bersikap aktif dikelas.

2. Kepala sekolah hendaknya terus-menerus melakukan pembinaan profesi bagi para guru matematika, hal tersebut penting karena pada dasarnya guru memegang peranan strategis dalam keseluruhan proses pembelajaran siswa di sekolah.

3. Bagi siswa hendaknya terus meningkatkan rasa percaya diri dan membangun keaktifan dikelas dalam upayanya meningkatkan prestasi belajar matematika.

\section{DAFTAR PUSTAKA}

Abdurahman, M. 2000. Matematika Sekolah Kejuruan. Jakarta: Erlangga.

Alwi, I. 2013. Statistika Untuk Penelitian. Jakarta: Saraz Publishing

Angelis, B. 2005. Confidence (Percaya Diri). Jakarta: Gramedia Pustaka.

Ardhana. 2009. Indikator Keaktifan Siswa Yang Dapat Dijadikan Penilaian dalam PTK. http//ardhana12.wordpress.com/2009/01/indikator-keaktifansiswa-yang-dapatdijadikan-penilaian-dalam-ptk-2, diakses tanggal 9 April 2014.

Astuti, A. \& Leonard. 2012. Peran kemampuan komunikasi matematika terhadap prestasi belajar matematika. Jurnal Formatif, 2 (2), 102-110.

Franky L. 2009.Pembelajaran Berpusat Pada Pembelajar. UPT-Pusat Sumberdaya Belajar Universitas Tarumanegara. AKADEMIKA Jurnal Pendidikan Universitas Tarumanegara. 11 (2), 145-166.

Hamalik, O. 2004. Proses Belajar Mengajar. Jakarta: Bumi Aksara

Hamdani, H. 2013. Pengembangan Sistem Pendidikan Indonesia. Jakarta: CV Pustaka Setia.

Holt, J. 2012. How Children Learn. Jakarta: Erlangga.

Holt, J. 2010. Mengapa Siswa Gagal. Jakarta: Erlangga.

Ikeda, D. 2012. The Way of Youth. Jakarta: PT Ufuk Publishing House Anggota IKAPI

Khoo, A. 2009. Iam Gifted So Are You. Jakarta: PT Elex Media Komputindo Kelompok Gramedia.

Kountur, R. 2009. Metode Penelitian untuk Penulisan Skripsi dan Tesis. Jakarta: Buana Printing.

Leonard. 2013. Kajian peran konsistensi diri terhadap prestasi belajar matematika siswa. Jurnal Formatif, 3 (2), 97-104.

Megawangi, R., dkk. 2008. Pendidikan Holistik. Jakarta: Indonesia Heritage Foundation

Mulya, N. R. 2012. Pengaruh sikap pada mata pelajaran kimia dan konsep diri terhadap prestasi belajar kimia. Jurnal Formatif, 2 (3), 218-226.

Nasution, D. 2010. Psikologi Pendidikan. Bandung: PT REMAJA ROSDAKARYA.

Nierenberg, G. I. 2012. Membaca Pikiran Orang Seperti Membaca Buku. Jogjakarta: DivaPress

Pabhichara, K. 2007. 12 Rahasia Pembelajar Cermelang. Bandung: Kolbu.

Sofan, A. \& Lif Khoiru Ahmadi. 2010. Konstruksi Pengembangan Pembelajaran Pengaruhnya terhadap Mekanisme dan praktik kurikulum. Jakarta: Prestasi Pustaka.

Supardi. 2013. Aplikasi Statistika dalam Penelitian edisi revisi. Jakarta: smart(Prima Ufuk Semesta).

Suprapto. 2013. Metodologi penelitian Ilmu Pendidikan dan Ilmu-ilmu Pengetahuan Sosial. Jakarta: CAPS (Centre for Academic Service Publisher). 
Susanto, Ahmad. 2014. Teori Belajar dan Pembelajaran di Sekolah Dasar. Jakarta: Kencana Prenadamedia Group.

Swadarma, doni \& Real Media Service. 2013. Penerapan Mind Mapping dalam Kurikulum Pembelajara. Jakarta: Elex Media Kompetindo

Syafaruddin dan Irwan Nasution. 2005. Manajemen Pembelajaran. Jakarta: Quantum Teaching.

Syah, Muhibbin. 2010. Psikologi Pendidikan. Bandung: PT. Remaja Rosda Karya.

Trianto. 2007. Model Pembelajaran Terpadu dalam Teori dan Praktek. Jakarta: Prestasi Pustaka.

Widiastuti, Niken dan Hilarion Erwin. 2009. Hubungan antara self-efficacy dengan mencontek pada remaja madya. Akademika, 11 (2), 145-166. 